\title{
Prediction of Longevity of Volunteer Service: A Basic Alternative Proposal
}

\author{
María Celeste Dávila de León and Fernando Chacón Fuertes \\ Universidad Complutense de Madrid
}

\begin{abstract}
A problem for many organizations is the low continuity of volunteers. Diverse theoretical models have been developed to explain sustained volunteerism, but most of these models have focused on the study of welfare volunteerism and not have verified whether their results could be generalized to other types of volunteerism. In this study, we propose a basic model to explain sustained volunteerism in any type of volunteerism. The aim of this study is to examine this basic model empirically in a sample of socio-assistential volunteers and in a sample of environmental volunteers. For this purpose, 290 volunteers completed a questionnaire and subsequently, two telephone follow-ups were carried out to determine whether the volunteers remained in the NGO one year later. The results show that the basic model offers an acceptable explanation of sustained volunteerism in the two types of volunteer samples studied, but it accounted for a low percentage of variance of the duration of service in both samples. Various relevant implications for the practical management of volunteerism in organizations are derived from theses findings. Keywords: volunteerism, retention, satisfaction, organizational commitment, intention to continue
\end{abstract}

\begin{abstract}
Uno de los problemas a los que se enfrentan muchas organizaciones es la escasa permanencia de los voluntarios. Para predecir la permanencia se han desarrollado diversos modelos teóricos, pero la gran mayoría se ha centrado en el estudio del voluntariado de carácter sociosanitario y no se ha comprobado si los resultados podrían generalizarse a otros tipos de voluntariado. En este trabajo se propone un modelo teórico básico que pueda explicar la permanencia de cualquier tipo de voluntariado, independientemente de las peculiaridades de los mismos. El objetivo de este trabajo es contrastar empíricamente en una muestra de voluntarios socioasistenciales y en una muestra de voluntarios medioambientales dicho modelo básico. Para ello, 290 voluntarios contestaron un cuestionario y participaron en dos seguimientos telefónicos durante un año para evaluar su permanencia en la organización. Los resultados muestran que el modelo básico propuesto obtiene un ajuste aceptable tanto en voluntarios socioasistenciales como en voluntarios medioambientales, aunque logra explicar reducidos porcentajes de varianza de la permanencia en ambos casos. De estos hallazgos se derivan distintas implicaciones para la gestión práctica del voluntariado en las organizaciones.

Palabras clave: voluntariado, permanencia, satisfacción, compromiso organizacional, intención de continuar
\end{abstract}

Correspondence concerning this article should be sent to $\mathrm{M}^{\mathrm{a}}$ Celeste Dávila de León, Dpto. de Psicología Social, Facultad de Sociología, Universidad Complutense de Madrid, Campus de Somosaguas, 28223 Madrid. Phone: 9139427 66. E-mail: mcdavila@cps.ucm.es

Translation: Virginia Navascués Howard 
Volunteerism is a social phenomenon that has expanded rapidly in Spain, but in the last few years, many people who are involved in volunteerism have noticed that it is undergoing a sort of stabilization process and, for some people, even a decline. Two of the most important problems faced by organizations at this time are the lower affluence of volunteers, more obvious in some sectors than in others, and their shorter permanence.

The study of volunteerism as a prosocial behavior has received attention from psychosocial investigators (Clary \& Snyder, 1991). Two questions can be considered the guides their study: What factors determine a person's decision to become a volunteer? What factors account for a person's continuing to volunteer once they have initiated this activity? Given the diversity that characterizes the phenomenon of volunteerism, we would qualify these questions with the following: Can one talk about different kinds of volunteerism? Does that which determines a person's decision to become and to remain a volunteer differ as a function of the type of volunteerism? According to the currently available evidence, we think that one can refer to different kinds of volunteerism, each one with its own idiosyncrasy, and that this must be taken into account when studying this social phenomenon. Wilson (2000) considers it problematic that the generic term "volunteerism" should cover such a broad and diverse variety of activities. This author indicates that it is probably not very helpful to attempt to explain all the activities with the same theory and to treat them all the same with regard to their consequences. Chacón and Dávila (2001) also consider that people perceive diverse volunteer activities differently and, depending on these perceptions, the activities can be grouped into types of volunteerism. Other proposals about the differentiation of volunteerism are, for example, that of Britton (1991) in volunteerism in disasters or that Marta, Rossi, and Boccacin (1999), focusing on the study of activities carried out by young people.

Most of the research on volunteerism has focused on socio-sanitary volunteerism, and a large part of the theoretical models currently developed were designed on the basis of this specific type of volunteers. Perhaps the most well known model is that of Omoto and Snyder (1995), in which is differentiated a series of antecedent variables (disposition to help, motivations, and social support) that, along with two process variables (satisfaction and organizational integration), accounts for volunteer permanence. Subsequently, other models were developed that started off from the influence generated by this model, such as the model of Davis, Hall, and Meyer (2003), whose main contribution to Omoto and Snyder's model was the inclusion of subjective experiences; or Vecina's (2001) model, which developed Omoto and Snyder's initial model, integrating more psychosocial variables, such as conflict or organizational support, and the intention to continue, a variable derived from the theory of reasoned action (Ajzen \& Fishbein, 1980; Fishbein \& Ajzen, 1975) and the theory of planned behavior (Ajzen, 1985).
Another model that has had some impact was the model of the volunteer's role-identity, designed by Piliavin and collaborators (Callero, Howard, \& Piliavin, 1987; Grube \& Piliavin, 1996; Piliavin \& Callero, 1991), which is based on the idea that being a volunteer for a long period of time increases one's commitment towards the organization, which, in turn, leads to an increase of actions favoring the organization. This leads people to assume the role of volunteer as part of their personal identity, which in turn leads to continuing to perform volunteer behaviors, because once this role is assumed, performing behaviors that are coherent with their identity is reinforcing to the individuals. Lastly, Penner's (2002) conceptual model of sustained volunteerism, still not empirically contrasted, somehow represents a synthesis of the results obtained up till now in volunteerism. This model distinguished three variables: the decision to become a volunteer (which refers to the moment when a person makes a commitment to volunteering), initial volunteerism (which refers to the time and effort that volunteers dedicate in the first stages of their volunteer permanence), and sustained volunteerism (which refers to the activity that volunteers carry out after a prolonged period of time as volunteers). According to this viewpoint, the decision to become a volunteer is more significantly explained by variables such as demographic characteristics, personal beliefs and values, prosocial personality, and motivation towards volunteerism, for example. Initial volunteerism is closely related to variables such as the decision to volunteer, attitudes towards the organization, and personal beliefs and values. Lastly, the volunteer role identity would be the key determinant of sustained volunteerism, which is weakly related to the remaining variables that explain, in general terms, both the decision to volunteer and initial volunteerism.

Some reflections can be derived from the above comments: How many theoretical models are there? If each one is different, although somewhat similar, how many can be generated? Which is the best model to account for longevity of volunteer service? The answers to these questions lead us to an issue proposed at the beginning of this introduction: The idiosyncrasies of each kind of volunteerism must be taken into account. But can we find a series of variables and relations among them that would allow us to explain permanence in any kind of volunteerism? If there were no common elements among the different types of volunteerism, it would be difficult to propose a generalizable explanatory model, but if we could identify a series of common elements, then we could develop a model that, despite the specific characteristics of each volunteerism, would be generalizable to any type.

Very diverse variables related to longevity of volunteer service have been analyzed (Omoto \& Snyder, 2002, Penner, 2002; Penner, Dovidio, Piliavin, \& Schroeder, 2005; Smith, 1994), despite which, according to the results of various investigations, a series of variables can be identified that seem to determine permanence in any type of volunteerism. 
Intention to continue in service is one of these variables. As stated in the theories of reasoned action and planned action, the prediction of a behavior is mediated by the intention of performing the behavior. The results found by Miller, Powell, and Seltzer (1990), Vecina (2001) and Greenslade and White (2005) reveal the implications of intention in the explanation of volunteerism. But the intention to perform a certain behavior is the result of a series of processes and influences.

In the last few years, it has become clear that attitudes towards the organization also play an important role in the explanation of volunteer permanence in the organization (Dailey, 1986; Gidron, 1985), and, in this sense, organizational commitment has been one of the most important predictors of permanence. Most of the investigations that study organizational commitment use a definition that is very similar to the one formulated by Porter, Steers, Mowday, and Boullian (1974): the individuals' belief in the values and goals of the organization, their satisfaction in making an effort to achieve those goals, and their desire to remain a member of the organization (Dailey). Omoto and Snyder's (1995) model includes this attitude, although it does not have a direct relation with permanence. In the model of volunteer role identity, organizational commitment plays an essential part in the assuming the volunteer role as an element of one's personal identity. Penner (2002) identified a construct he called "relationship with the organization," that includes organizational attitudes such as job satisfaction and organizational commitment, and which have a direct relation with what he called initial volunteerism, and a weaker relation with sustained volunteerism. Lastly, Miller et al. (1990) identified a construct they called "attitudinal factors" and which, as in the previous instance, includes organizational commitment and satisfaction, but in this case, their influence on early termination of volunteer service is mediated by behavioral intention.

Satisfaction is another variable that many investigations have related to permanence. It has been traditionally associated with organizational commitment, both in remunerated personnel (Hall \& Schneider, 1972; Porter et al., 1974; Stevens, Beyer, \& Trice, 1978) and in volunteerism (Dailey, 1986), and, in fact, most researchers consider satisfaction a good predictor of organizational commitment (Bateman \& Strasser, 1984; Dailey; Hall, \& Schnieider). On the one hand, there is satisfaction regarding motivations, more closely related to intrinsic satisfaction with the work itself. People attempt to satisfy their personal needs by choosing and engaging in behaviors that they believe will satisfy them. Satisfaction with these activities is thus generated to the extent to which they feel their motivations for becoming involved in these activities are realized (Kiviniemi, Snyder, \& Omoto, 2002). On the other hand, satisfaction can also be more specifically concerned with the context in which the work is performed. From work and organizational psychology, satisfaction is defined as the degree of pleasure that employees obtain from their work (Muchinsky, 2000).

In this study, we present a proposal that includes the above-mentioned variables to predict permanence in any type of volunteerism: the basic model. In this model, satisfaction predicts organizational commitment, which, in turn, predicts the intention of continuing in service, and this last construct is directly related to permanence (see Figure 1). This basic structure of relations will establish the foundation that will secure permanence, but depending on the kind of activity of the volunteers or on other factors that differentiate volunteers, a series of specific factors will be added to allow us to configure the idiosyncrasies of each kind of volunteerism and so, explain their permanence.

The aim of this investigation is to determine empirically whether the basic model is capable of adequately predicting permanence of different kinds of volunteerism.

The choice of the types of volunteers to be studied comes from one of the classifications proposed by Chacón and Dávila (2001) for the organization of studies of volunteerism. In this classification, volunteers who perform assistential, training, and management and administration activities are distinguished from volunteers who perform field activities for the protection of the natural environments. The second category includes a kind of volunteerism that has received little attention from researchers, despite the social relevance of these activities and of the significant number of volunteers in this area.

\section{Method}

\section{Participants}

In this study, 290 volunteers from 27 different organizations participated. Of the sample, $51.7 \%$ (150) performed assistential, training, or administrative and management activities (hereafter, socio-assistential volunteers) and $48.3 \%$ (140) performed field activities aimed at environmental defense or the protection of certain species (hereafter, environmental volunteers).

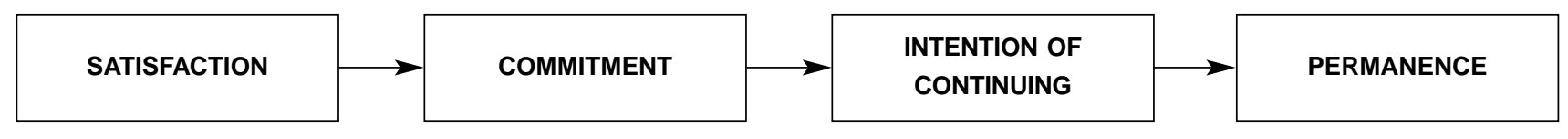

Figure 1. Basic model. 
Regarding sex, $50 \%$ of the sample were women and $50 \%$ were men. Age ranged between 16 and 81 years, mean age of 32 ( $S D=13$ years, approximately). With regard to educational level, $9 \%$ had primary studies, $35.8 \%$ secondary studies, and $55.2 \%$ had university studies.

Among the socio-assistential volunteers, $71.5 \%$ were women and $28,5 \%$ were men, their ages ranged between 16 and 81 years, mean age 36 years $(S D=16$ years, approximately). Of this group, $10.6 \%$ had primary studies, $36.4 \%$ secondary studies, and $53 \%$ university studies.

Of the environmental volunteers, $73.6 \%$ of the sample were men and the remaining $26.4 \%$ were women. Their ages ranged between 17 and 67 years ( $S D=9$ years, approximately). Of this group, $7.1 \%$ had primary studies, $35 \%$ secondary studies, and $57.9 \%$ university studies.

\section{Instruments}

General satisfaction achieved by the volunteers from their activities was assessed on a 7-point scale, and more specifically, by rating volunteer experience from 1 to 7 on 4 descriptors: satisfactory, rewarding, interesting, and disappointing. Internal consistency of these five items was .69.

To assess organizational commitment, we used a reduced version of the Organizational Commitment Questionnaire (OCQ; Mowday, Steers, \& Porter, 1979), adapted to the Spanish population and to volunteerism by Dávila and Chacón (2003). This is a 9-item questionnaire with a 7-point Likert type response format, ranging from 1 (totally disagree) to 7 (totally agree). Examples of items are: "I am willing to put in a great deal of effort beyond that normally expected in order to help this organization be successful," "I find that my values and the organization's values are very similar," "For me, this is the best of all possible organizations for which to work." Internal consistency of .88 was obtained in the current study with this instrument.

We also employed one of the measurements used by Omoto and Snyder (1995) to study integration within the organization, specifically, the items that refer to acceptance of the philosophy, goals, and purposes of the organization. Responses were rated on 7-point Likert type scales, ranging from 1 (totally disagree) to 7 (totally agree). The internal consistency obtained with these three items was .76. In this case, the mean of these three items was used as an indicator of the construct of organizational commitment.

Intention to remain in service was operationalized by an item in which volunteers were asked to appraise the likelihood of their continuing with their volunteer activity one year later. Responses were rated on a 7-point Likert type scale, ranging from 1 (not at all likely) to 7 (extremely likely).

Finally, real permanence duration consisted of the number of months gone by since volunteers responded to the questionnaire either until they decided to terminate their volunteer service or, contrariwise, they remained in service at the 12-month follow-up. Thus, the maximum permanence duration was one year.

\section{Procedure}

The conditions to administrate the questionnaires were agreed on with each organization to interfere as little as possible with its habitual functioning. In some cases, a person from the organization distributed and collected the questionnaires. In others, this person provided a list with the volunteers' addresses, and they received the questionnaires by mail with a stamped envelope in which to return them. And in some cases, the questionnaires were sent out by e-mail and the volunteers could either return them by normal post, e-mail, or fax to the person from the organization or to the principal researcher.

After collecting the first series of measurements, two telephone follow-up calls were made to determine permanence in the NGO; one at the 6-month interval, and one at the 12-month interval. Out of the 290 volunteers that made up the initial sample, 70 had discontinued their service at the first follow-up, and 29 volunteers had dropped out at the second follow-up one year later.

The different procedures employed to collect the data may have affected the volunteers' responses, but we thought that if we did not adjust to the requirements of the organizations, collaboration rates would be lower.

\section{Results}

In order to verify the predictive power of the proposed basic model in the two samples of volunteers, we used the structural equations models of the computer program AMOS 4.0.

In Table 1 are displayed the fit indexes obtained with each type of volunteerism. As can be seen, these indexes show a fit to the empirical data that is, in general, acceptable: $\chi^{2}(25$, $N=150)=33.798, p=.112$, for the socio-assistential volunteers, and $\chi^{2}(25, N=140)=35.194, p=.085$, for the environmental volunteers. Regarding other fit indexes studied, the values of the goodness-of-fit index (GFI), the root mean square error of approximation (RMSEA), the adjusted goodness-of-fit index (AGFI), the normed fit index (NFI), the incremental fit index (IFI), and the normed chi-square index can, in most cases, be considered acceptable (see Table 1).

Upon examining the structural fit of the model, it can be observed that the data obtained are also favorable (see Figure 2). All the relations hypothesized by the model are statistically significant, both for socio-assistential and for environmental volunteers:

1. The direct relation between satisfaction and organizational commitment was significant (C.R. = 4.424 and C.R. $=4.671$, respectively, for socioassistential and environmental volunteers). 
Table 1

Goodness-of-Fit Indexes Obtained with each Type of Volunteerism

\begin{tabular}{lccccccccc}
\hline Volunteerism & $\chi^{2}$ & $d f$ & $p$ & GFI & RMSEA & AGFI & NFI & IFI & $\chi^{2} / \mathrm{df}$ \\
\hline Socio-assistential & 33.798 & 25 & .112 & .953 & .048 & .915 & .908 & .974 & 1.351 \\
Environmental & 35.194 & 25 & .085 & .948 & .054 & .907 & .863 & .956 & 1.407 \\
\hline
\end{tabular}

2. The direct relation between commitment and intention to continue in service was significant (C.R. $=6.339$ and C.R. $=4.47$, respectively, for socio-assistential and environmental volunteers).

3. The direct relation between intention to continuing service and permanence duration was significant (C.R. = 5.602 and C.R. = 3.801, respectively, for socio-assistential and environmental volunteers).

The only problem that the model presents is the low percentage of variance accounted for by real permanence duration, both in socio-assistential and in environmental volunteers, $17 \%$ and $9 \%$, respectively, for socio-assistential and environmental volunteers.

\section{Discussion}

In this study, we presented a basic model to predict permanence in any type of volunteerism. Our model includes satisfaction, organizational commitment, intention of continuing in service, and real permanence duration and the relations among them. In general, the results show that the basic model presents an acceptable fit both to the data of the environmental volunteers and to the socio-assistential volunteers. The confirmation of the basic model in these two samples supports the hypothesis about the possibility that volunteer permanence can be partially explained by a basic structure of relations that is shared by any type of volunteerism.
Acceptance of the basic model would involve important practical implications. As noted by Vecina (2001), the variable intention to remain in service was shown to have important predictive power for real permanence duration. If one wishes to predict permanence with just one question, the best option would be to ask volunteers how long they plan to remain in service. The response to this question can not only be a good estimate of the volunteer's stability, but it also establishes a minimum commitment towards which the volunteer will try to act consequently (Vecina).

However, if one proposes to advance in active management of volunteerism and to achieve the longest possible permanence, only knowing the volunteers' intentions is not enough. These intentions are the result of a series of processes and influences that may be affected by organizational variables, subject in turn, to some extent, to the active management of volunteerism. At this point, organizational commitment may act as an important catalyzer that promotes intentions that, in turn, enhance permanence. Organizational commitment is one of the subjects studied in Work and Organizational Psychology that has recently aroused the most interest because it is considered one of the best predictors to the success of organizations (Antón, 1999).

Another organizational variable studied is satisfaction with the work, which seems to act as a predictor of commitment (Antón, 1999). According to the basic model, if one wishes to increase volunteer permanence, one should implement a series of strategies to increase satisfaction with

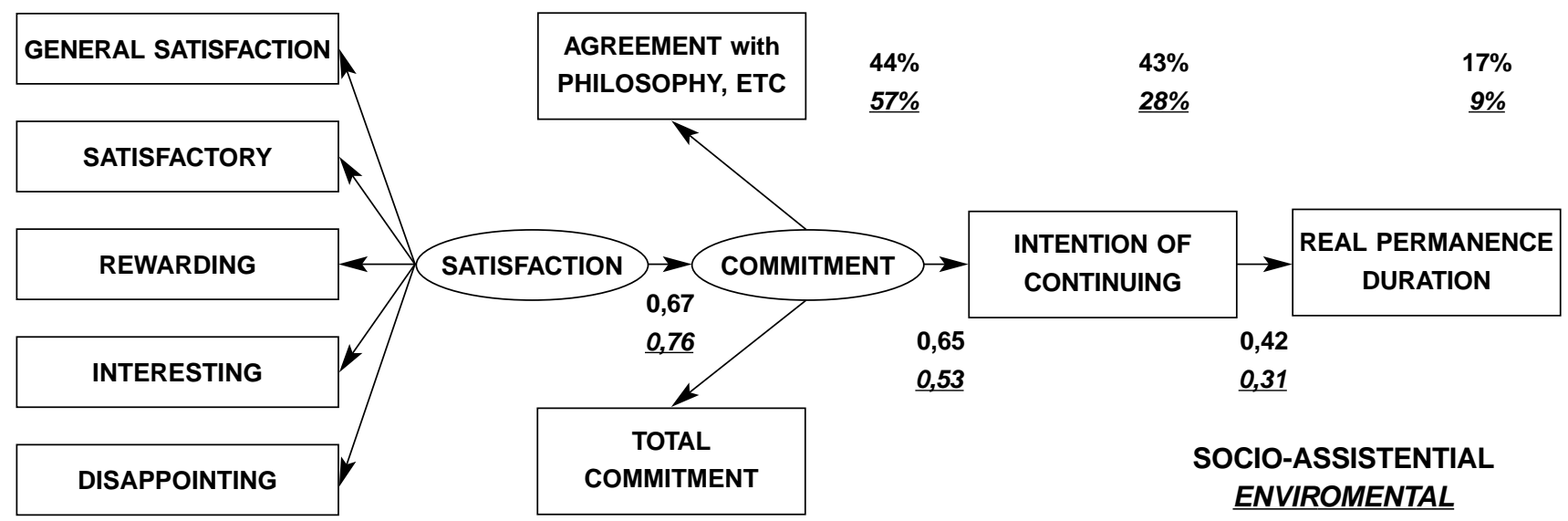

Figure 2. Graphic representation of the basic model, with standardized regression weights between the constructs studied (satisfactioncommitment, commitment-intention of continuing, intention-permanence) and percentages of explained variance obtained for organizational commitment, intention of continuing, and volunteer permanence. 
the activity, which would lead to higher commitment and, so, to the intention of continuing, which is ultimately what directly predicts permanence. Increased volunteer satisfaction could be promoted, for example, by implementing certain incentive policies, or management strategies, or by creating working environments that allow people to satisfy the needs that motivated them to become volunteers in the first place.

Although the proposed basic model coincides with some theoretical assumptions that explain employee permanence within organizations, obviously, an employee's remunerated work relationship with an organization is not the same as the relationship that a volunteer may have with an organization. There are many nuances and differences that should be taken into account when studying both organizational commitment and satisfaction and their implications for longevity of volunteer service. However, one of the conclusions of this investigation is that we need to study in more depth many of the human resources management strategies that lead to generating workers' organizational commitment and satisfaction, as they may be useful to guide practical volunteer management.

Despite the acceptable fit of the model, its most important handicap is the low percentage of variance accounted for by permanence duration. This may be coherent with the fundamental proposal of the model, because another series of variables would reflect the idiosyncrasies of each type of volunteerism and complement the basic model, thus producing different specific models for each type of volunteerism, which would allow us to explain an acceptable percentage of variance of permanence duration.

The results also reveal the need for the study of volunteerism to be sensitive enough to the peculiarities of each type of volunteerism and, therefore, the risk of overgeneralizing some findings. Specifically, the idiosyncrasy of environmental volunteerism is revealed not only in the differences found regarding the fit of the explanatory model, but also in the lower percentages of explained variance in comparison to socio-assistential volunteerism.

\section{References}

Ajzen, I. (1985). From intentions to actions: A theory of planned behavior. In J. Jul \& J. Beckmann (Eds.), Action-control: From cognitions to behaviors (pp. 11-39). New York: Springer.

Ajzen, I., \& Fishbein, M. (1980). Understanding attitudes and predicting social behavior. Englewood-Cliffs, NJ: Prentice-Hall.

Antón, C. (1999). Las tres dimensiones del compromiso organizacional: un modelo causal. Unpublished doctoral dissertation, University of Salamanca (Spain).

Bateman, T., \& Strasser, S. (1984). A longitudinal analysis of the antecedents of organizational commitment. Academy of Management Journal, 27, 95-112.

Britton, R.N. (1991). Permanent disaster volunteers: Where do they fit? Nonprofit and Voluntary Sector Quarterly, 20, 395-414.
Callero, P., Howard, J.A., \& Piliavin, J.A. (1987). Helping behaviour as role behaviour: Disclosing social structure and history in the analysis of prosocial action. Social Psychology Quarterly, 50, 247-256.

Chacón, F., \& Dávila, M.C. (2001). Construcción de una tipología cognitiva sobre actividades de voluntariado. Psicología Social Aplicada, 12, 35-59.

Clary, E.G., \& Snyder, M. (1991). A functional analysis of altruism and prosocial behavior: The case of volunteerism. In Clark, M.S. (Ed.), Prosocial Behavior, Vol. 12. Review of Personality and Social Psychology (pp.119-148). London: Sage.

Dailey, R.C. (1986). Understanding organizational commitment for volunteers: Empirical and managerial implications. Journal of Voluntary Action Research, 15, 19-31.

Dávila, M.C., \& Chacón, F. (2003). Adaptación de instrumentos para la evaluación de aspectos organizacionales en ONG's. Revista de Psicología del Trabajo y de las Organizaciones, 19,159-179.

Davis, M.H., Hall, J.A., \& Meyer, M. (2003). The first year: Influences on the satisfaction, involvement and persistence of new community volunteers. Personality and Social Psychology Bulletin, 29, 248-260.

Fishbein, M., \& Ajzen, I. (1975). Belief, attitude, intention and behavior: An introduction to theory and research. Reading, MA: Addison-Wesley.

Gidron, B. (1985). Prediction of retention and turnover among service volunteer workers. Journal of Social Service Research, $8,1-16$.

Greenslade, J.H., \& White, K.M. (2005). The prediction of aboveaverage participation in volunteerism: A test of the Theory of Planned Behavior and the Volunteers Functions Inventory in older Australian adults. The Journal of Social Psychology, 145, 155-172.

Grube, J., \& Piliavin, J.A. (1996). Role identity, organizational commitment, and volunteer performance. Paper presented at the annual meeting of Society for the Psychological Study of Social Issues. Ann Arbor, MI.

Hall, D.T., \& Schneider, B. (1972). Correlates of organizational identification of career pattern and organizational type. Administrative Science Quarterly, 17, 340-350.

Kiviniemi, M.T., Snyder, M., \& Omoto, A.M. (2002). Too many of a good thing? The effects of multiple motivations on stress, cost, fulfillment, and satisfaction. Personality and Social Psychology Bulletin, 28, 732-743

Marta, E., Rossi, G., \& Boccacin, L. (1999). Youth, solidarity, and civic commitment in Italy: An analysis of the personal and social characteristics of volunteers and their organizations. In M. Yates \& J. Youniss (Eds.), Roots of civic identity: International perspectives on community service and activism in youth (pp. 73-96). Cambridge: Cambridge University Press.

Miller, L.E., Powell, G.N., \& Seltzer, J. (1990). Determinants of turnover among volunteers. Human Relations, 43, 901-917.

Mowday, R.T., Steers, R.M., \& Porter, L.W. (1979). The measurement of organizational commitment. Journal of Vocational Behavior, 14, 224-247. 
Muchinsky, P. (1993). Organizational behaviors and attitudes. In P. Muchinsky (Ed.), Psychology applied to work: An introduction to industrial and organizational psychology (4th ed.). Pacific Grove, CA: Brooks/Cole [Spanish translation: Conductas y actitudes organizativas. In P. Munchinsky (Ed.), Psicología aplicada al trabajo (pp. 237-261). Madrid: Paraninfo, 2000.]

Omoto, A.M., \& Snyder, M. (1995). Sustained helping without obligation: Motivation, longevity of service, and perceived attitude change among AIDS volunteers. Journal of Personality and Social Psychology, 68, 671-686.

Penner, L.A. (2002). Dispositional and organizational influences on sustained volunteerism: An interactionist perspective. Journal of Social Issues, 58, 447-467.

Penner, L.A., Dovidio, J.F., Piliavin, J.A., \& Schroeder, D.A. (2005). Prosocial behaviour: Multilevel perspectives. Annual Review of Psychology, 56, 365-392.

Piliavin, J.A., \& Callero, P.L. (1991). Giving blood: The development of an altruistic identity. Baltimore, MD: Johns Hopkins University Press.
Porter, L.W., Steers, R.M., Mowday, R.T., \& Boulian, P.V. (1974). Organizational commitment, job satisfaction and turnover among psychiatric technicians. Journal of Applied Psychology, 59, 603-609.

Smith, D.H. (1994). Determinants of voluntary association, participation and volunteering: A literature review. Nonprofit and Voluntary Sector Quarterly, 23, 243-263.

Stevens, J.K., Beyer, J.M., \& Trice, H.M. (1978). Assessing personal, role, and organizational predictors of managerial commitment. Academy of Management Journal, 21, 380-396.

Vecina, M.L. (2001). Factores psicosociales que influyen en la permanencia del voluntariado. Unpublished doctoral dissertation, Universidad Complutense de Madrid.

Wilson, J. (2000). Volunteering. Annual Review of Sociology, 26, 215-240.

Received March, 27, 2006 Revision received September, 1, 2006 Accepted November, 10, 2006 